\title{
Determinants of Innovative Performance: The Case of an Emerging Country SMEs
}

\footnotetext{
Submitted 14/06/20, 1st revision 17/07/20, 2nd revision 06/08/20, accepted 30/09/20

Ainul Mohsein Abdul-Mohsin ${ }^{1}$, Hasliza Abdul Halim², Noor Hazlina Ahmad ${ }^{3}$

Abstract:

Purpose: Malaysia aspires to vie with other developed countries and achieve similar status shortly. Thus, to generate a more knowledge-intensive and innovation-driven economy is crucial for the country. Considering the significance that an Innovation Economy is designed from an amalgamation of knowledge, technology, entrepreneurship, and innovation to hasten productivity, which is the core of economic growth; this study analyzed the relationship of entrepreneurial attitude orientation (EAO), market orientation, and entrepreneurial competencies to competitive intelligence and its impact on the innovative performance of SMEs in Malaysia.

Approach/Methodology/Design: This study adopted a cross-sectional research design and collected data from small, medium enterprises from 13 states and two federal territories of Malaysia.

Findings: The findings revealed that market orientation has a positive impact on entrepreneurial competencies. It is also found that EAO constructs, in particular conceptual, strategic, and technical competencies, have a significant relationship with competitive intelligence and thereby have an impact on the Malaysian SMEs. Likewise, competitive intelligence positively influences the innovative performance.

Practical Implications: Apart from contributing to the body of existing literature on innovative firm performance, the study gives a guideline to the SMEs, government agencies, and universities to create the database and designing their training and development programs to cultivate the sense of innovativeness among Malaysians regardless of age, race, and education background.

Originality/Value: This study contributes by supporting that conceptual, strategic, and technical competencies have a significant relationship with competitive intelligence and is achievable to be used by SMEs.
}

Keywords: Entrepreneurial attitude orientation, market orientation, entrepreneurial competencies, competitive intelligence, innovative performance, SMEs.

JEL classification: L26, M31, O31,O39, O53.

Paper Type: Research Paper.

Acknowledgements: Work by the authors were funded and supported by the School of Management, Universiti Sains Malaysia.

\footnotetext{
${ }^{1}$ International Business Section, School of Management, Universiti Sains Malaysia, Malaysia,e-mail: ainabdulmohsin@usm.my

${ }^{2}$ Organisational Behavior Section, School of Management, Universiti Sains Malaysia,

Malaysia e-mail: haslizahalim@usm.my

${ }^{3}$ Organisational Behavior Section, School of Management, Universiti Sains Malaysia, Malaysiae-mail: hazlina@usm.my
} 


\section{Introduction}

SMEs are extensively known as important national development mechanisms in modern, technologically advanced, and unindustrialised economies. In Malaysia, SMEs took part in the national development by filling the economic gaps unattended by the macro or large-scale organizations (Chatterjee and Das, 2016; Ratnawati, Soetjipto, Murwani, and Wahyono, 2018). According to Poon, Mohamad, and Wan Yusoff (2018), micro-entrepreneurial activities can enhance the local economy to fulfill the residents' standard of living and hence are considered fundamental to accumulate assets. More than $95 \%$ of the business entities in the world today can be classified as SMEs (Heslina, Payangan, Taba, and Pabo, 2016) that contribute more than 36 percent to the Gross Domestic Product and over 60 percent to employment. Hence many nations who aspire to be a high-income nation have revamped their countries' SMEs.

The reason behind a nation's success is its substantial investment in its SMEs' innovation capability by leveraging on its competitive intelligence (Kim and Ha, 2010). Although the concept of competitive intelligence (CI) is not strange in business, it has been disregarded by many organizations, especially within the SMEs. CI's effectiveness is evident when the Republic of Korea dramatically improved its economy and became the world's 11th largest economy by 1995 (International Monetary Fund, 2014). It could be argued that Malaysia could follow neighbors like the Republic of Korea and Taiwan in these regards to become a fully advanced, modernized, and industrialized-based country by advancing SME growth through CI. Unfortunately, there have been limited studies to discover the interior factors that would impact CI's endeavor by Malaysian SMEs. Therefore, important aspects, including attitudes, competencies, strategies, and administrative or planning skills, are disregarded (Carrier, 2007). In a related context, Stokes and Blackburn (2002) suggested that the organization's innovation success relies on the entrepreneurs' attitude, competencies, and business direction, which is worth examining. Hence based on the above, we attempt to bridge the gap in the literature by examining the relationships of variables that are important to the survival of Malaysian SMEs, such as market orientation, entrepreneurial attitude orientation, entrepreneurial competencies, and competitive intelligence (Choe, Loo, and Lau, 2013) to improve innovative performance.

\section{Literature Review}

\section{Theoretical Foundation}

To develop a solid theoretical research framework that integrates entrepreneurial attitude orientation, market orientation, enterprising abilities, competitive intelligence, and innovative performance, the study employs the Resource-BasedView (RBV) as its supporting theory. RBV remains well established in existing product innovation literature (Freel and de Jong, 2009; Kumar and Sanchez Rodrigues, 2020). RBV emphasizes that to achieve competitive/innovative 
advantage from the organization's resources, incorporating various resources is the key to shaping solid organizational capabilities. This study emphasizes understanding the relationship between EAO, EC, CI, and IP because, according to Tywoniak (2007), attitude or the sense-making perspective is biased towards 'bounded cognition' which is the construction of the mind that select, acknowledge data, and later direct the behavior and performance. Entrepreneurs make choices based on their perception or attitude, which directly relates to their learning, competencies, and adaption ability. Their learning process is proven to have been impacted by entrepreneurial cognition and cognitive biases (Tripsas and Gavetti, 2000). Furthermore, affective attitude is a strong indicator of entrepreneurship (Vamvaka, Stoforos, Palaskas et al., 2020). It is self-evident that attitude can influence competencies.

Also, RBV corresponds that entrepreneurial competencies are important resources for increasing and sustaining competitive edge/innovation (Vijaya, Manjula, and Mitrabindha, 2015). The RBV is also used to extend the idea that CI within an organization is a valuable resource, asset, and capability because CI is a process and a product. $\mathrm{CI}$ is a rare resource and acts as a competitive advantage by adding an organization to develop and implement strategies that enhance its effectiveness and efficiency (Daft, 1983). In CI, the final course of action is for the entrepreneur to decide for the organization's betterment after obtaining all the intelligence. According to Charity and Joseph (2013), an organization with a proactive CI process will respond quicker and wiser to markets and competitors' changes in the long term in a highly dynamic competitive market. The CI's utilization can also help the organization understand how competitors build their exclusive capabilities and assets, access competitors' ability to duplicate others and assess bundle resources to create value to the stakeholders uniquely. One important aspect of $\mathrm{CI}$ is that it is an integral practice within the strategy (Maritz and du Toit, 2018). This strongly suggests that CI status as a rent-producing asset can be proven in many ways. Based on the RBV literature above, it could be conjectured that attitude, strategies, and competencies play an important role in innovative performance. Apart from the RBV, we summoned the dynamic capabilities concept in this study to support the framework portraying the association of MO with entrepreneurial competencies, competitive intelligence, and innovative performance. Strong dynamic capabilities are the critical success factor for an organization that wants to pioneer a market or innovate and extend a product category. Dynamic capabilities are pivotal for innovation and competitive advantage in business, as confirmed in Zheng, Zhang and Du (2011), and improve firm performance (Zhou, Zhou, Feng and Jiang, 2019). Hence, based on the aforesaid, this study propounds that the forwarded theory may build dynamic capabilities and promote innovative performance.

Finally, the study also utilizes the entrepreneurial competency concept. According to Bird (1995), entrepreneurial competencies are the underlying characteristics of an individual that can be general or specific knowledge, motives, traits, self-images, social roles, and skills which bring about the initiation, endurance, and development 
of an organization. The idea of entrepreneurial competency supports the RBV to advocate that competencies are crucial and valuable resources. Such resources include the intangible resources, which is the acceptable attitude of the members of the organization. Therefore, this study contends that it is fundamental to recognize the entrepreneur attitude and market orientation and their relationship to entrepreneur competencies, which facilitates competitive intelligence, leading towards superior, innovative performance among Malaysian SMEs.

\section{Entrepreneurial Attitude Orientation (EAO)}

EAO is very consistent in measuring an entrepreneur's demeanor towards the processes, practices, and decision making (Pihie and Bagheri, 2010; Shariff and Saud, 2009). Sánchez-Báez, Fernández-Serrano, and Romero (2018) noted that entrepreneurial attitudes positively mediate innovation. The entrepreneurial attitude orientation contains four dimensions, but conceptually only three dimensions are typically related to business motivation. They include the need for achievement, locus of control, and innovation (Qiu, 2008). The connection between entrepreneurs' EAO and EC and CI is crucial to be explored as their entrepreneurial attitude affects SMEs' decision making (Smith, Wright, and Pickton, 2010). EAO incorporates an attitude scale to predict the entrepreneurial orientations that are more domainspecific, which increases its correlation with the actual behavior. Since attitude is the key to understanding EC and CI, part of this research will also analyze EAO and EC's link. This effort is necessary considering the inadequacy of findings on the impact entrepreneurial attitude on entrepreneurial competencies and innovative performance on SMEs in Malaysia.

\section{Market Orientation}

In management studies, Market Orientation (MO) is perceived as a major aspect of business strategy for viewed as the main strategic orientation and development of specific positioning strategies (Hunt and Lambe, 2000; Pramod, Davari, Zolfagharian and Paswan, 2019 ). To remain in front of its respective markets, MO demands organizations to develop a market sensing capability. In this study, MO comprises two behavioral parts: customer orientation and competitor orientation (Narver and Slater, 1990). The reason to limit the selections is because the study is on SMEs and many of these organizations have limited staff and not many departments. MO is considered market scanning and therefore is a subset of CI and relates well with this study's focus, examining the relationship between MO and EC.

\section{Entrepreneurial Competencies}

Entrepreneurial competencies (EC) suggests the "underlying characteristics such as specific knowledge, motives, traits, self-images, social roles, and skills which result in venture birth, survival, and/or growth" (Bird, 1995). In the context of this study, EC describes entrepreneurs' general business skills, including enterprising, managerial, and technical expertise (Man, Lau, and Chan, 2002). A Finnish study by Taipale-Erävala, Henttonen, and Lampeda (2019) relates that entrepreneurs with EC such as preparedness and proactiveness are inclined to be innovative. The two 
capabilities are what CI is based on. The EC selected from Man (2001) for this study are entrepreneurial competencies from the behavioral perspective, namely, opportunity, strategic, relationship, and conceptual competencies that are expected to affect the CI process in any possible way.

\section{Competitive Intelligence}

Competitive Intelligence (CI) has gained increasing importance in the last few decades. CI has proved to be a valuable tool in today's convoluted and unstable global environment. Although CI has gained popularity among the larger organizations, it remains poorly studied in the academic literature (Calof and Wright, 2008) with limited empirical studies in SMEs' context (Tarraf and Molz, 2006). However, despite the lack of empirical evidence portraying CI's impact on SMEs, small organizations have shown interest in CI as a tool that allows entrepreneurs to remain alert and avert business risk (Zha and Chen, 2009). In the past years, few countries have intervened to attract entrepreneurs' attention to apply CI in SMEs and provide help in the skill development as part of the effort (Larivet, 2009; Smith et al., 2010; Thalassinos and Thalassinos, 2018). For example, Tarraf and Molz (2006) confirmed that small multimedia organisations in Canada regard CI activity is crucial to their businesses' success. African SMEs substantiated that SMEs are applied CI to remain competitive (Tarek, Zouhayer and Adel, 2019). An organization is that SMEs that practices CI can anticipate technological and potentially disruptive innovation (Vargas and Perez, 2017). Although the literature on CI management in Asia has grown in the last decade, it is still underdeveloped in Malaysia. Research on CI use has to be stepped up because CI can be a vital tool in the strategic business formulation and gain competitive advantages among Malaysia's business organizations regardless of their size.

\section{Innovative Performance}

In the business sector, any SMEs' survival is determined by its knowledge, technology, and innovation in entrepreneurship, parallel to the current globalized world. Additionally, innovation enhances existing knowledge and opens to new ideas, as Rogers (2008) explained. Similarly, Damanpour (1996) postulated that inventiveness might not be applied only to business processes and product, but it also includes business managerial. As agreed by many authors, SMEs' survival is also determined by its entrepreneurial competencies, which will stimulate innovation. These competencies that precede CI activities influence an organization's innovative performance (Nag, Neville, and Dimotakis (2020). This research is product incremental innovation because SME mainly focuses on the gradual improvement of its products/services and processes compared to larger organizations that typically opt for radical innovation (Baregheh, Rowley, Sambrook, and Davies, 2012). Thus, it is crucial to analyze the connection between CI and innovativeness in Malaysian SME.

\section{Methodology}


Population, Sample, and Research Instrument

The target population of this study was the Malaysian SMEs from diverse sectors. In order to choose the right participants, information was collected from SME Corporation Malaysia. Using purposive sampling and applying the criteria inclusion technique, a list of 1000 out of 1050 SMEs were selected from organizations owned by Malaysian entrepreneurs. 15 out of 1000 were used for pre-testing. In this study, the mail survey was employed because of its wider coverage. In this study, 167 samples were collected by the researcher following the suggestion by Hair et al. (2010), which recommend 50 samples as the minimum number to conduct a multivariate analysis. Nevertheless, the statistical $G^{*}$ Power analysis suggested (Faul, Erdfelder, Buchner and Lang, 2009) that the minimum sample size with a medium effect size of 0.15 is 138 . Both requirements are met in this research sampling size. A questionnaire was used as the main tool in this study to collect data. The questionnaire items were modeled on the past studies by Robinson et al. (1991); Narver and Slater (1990); Man et al. (2008); Ahmad (2007), Chandler and Jansen (1992); Saayman et al. (2008); as well as Johannessen et al. (1997).

Common method variance (CMV) and Data Analysis

A self-report survey was used in this study to obtain the response of CEOs/owners of SMEs, and the questionnaire was created specifically so that only they could respond. Thus, the issue of common method variance is unavoidable. Nevertheless, to limit the issue of variances, this study conducted a pre-testing procedure and the statistical Harman-single factor test. It was found that the single factor concern did not arise, and the common method variance was not a major issue. As for statistical remedy to address CMV, we employed the SPSS, and the fun-rotated factor Eigenvalue was greater than one criterion analysis. The result shows that 15 factors explain $74.86 \%$ of the variance, while the first factor explains $36.24 \%$ of the variance from the data collected. Therefore, neither a single factor nor one general factor accounts for the majority of the total variance. In conclusion, the data collected was not likely to be contaminated by the common methods biases. This study used SPSS version 22 and SmartPLS 3.0. SPSS version 22 was used for data input, screening, demographic profiling, and descriptive statistics, whereas the SmartPLS was used for hypothesis testing using Structural Equation Model (SEM) utilizing the Partial Least Square approach.

\section{Results}

From the respondents in Table 1, 65 were from the manufacturing sector, and 102 were from the services and others sector. Majority of the respondents have been operating their enterprises between 4 and 10 years $(31.14 \%)$, and $25.15 \%$ have been operating for 21 years or more. The majority are micro-size businesses run by most of the respondents of the survey $(43.71 \%)$, followed by small size businesses $(37.13 \%)$ and medium-size businesses (19.16\%). Majority of the respondents run private limited companies $(61.08 \%)$. The largest group of the respondents in this 
study are recorded between 40-49 (28.14\%) years old and the highest level of education attained by most of the respondents is the degree level $(52.69 \%)$.

Table 1. Socio-demographic profile of the participants

\begin{tabular}{|c|c|c|c|c|c|}
\hline Demographics & Category & Manufacturing & Services & Frequency & Percentage \\
\hline \multirow{5}{*}{$\begin{array}{l}\text { Years in } \\
\text { Operation }\end{array}$} & 3 years only & 12 & 28 & 40 & 23.95 \\
\hline & between $4-10$ & 23 & 29 & 52 & 31.14 \\
\hline & $\begin{array}{l}\text { between } 11- \\
15\end{array}$ & 3 & 9 & 12 & 7.19 \\
\hline & $\begin{array}{l}\text { between 16- } \\
20\end{array}$ & 14 & 7 & 21 & 12.57 \\
\hline & above 21 & 13 & 29 & 42 & 25.15 \\
\hline $\begin{array}{l}\text { Respondent is } \\
\text { the Owner of } \\
\text { the } \\
\text { Organisation }\end{array}$ & YES & 65 & 102 & 167 & 100.00 \\
\hline \multirow{3}{*}{$\begin{array}{l}\text { SMEs Criteria } \\
\text { (Micro, Small } \\
\text { or Medium) }\end{array}$} & Micro & 16 & 57 & 73 & 43.71 \\
\hline & Small & 34 & 28 & 62 & 37.13 \\
\hline & Medium & 15 & 17 & 32 & 19.16 \\
\hline \multirow[t]{3}{*}{$\begin{array}{l}\text { Types of } \\
\text { Ownership }\end{array}$} & $\begin{array}{l}\text { Sole } \\
\text { Proprietorship }\end{array}$ & 8 & 30 & 38 & 22.75 \\
\hline & Partnership & 6 & 21 & 27 & 16.17 \\
\hline & $\begin{array}{l}\text { Private } \\
\text { Limited }\end{array}$ & 51 & 51 & 102 & 61.08 \\
\hline \multirow[t]{2}{*}{ Gender } & Male & 45 & 59 & 104 & 62.28 \\
\hline & Female & 20 & 43 & 63 & 37.72 \\
\hline \multirow{6}{*}{$\begin{array}{l}\text { SME } \\
\text { Entrepreneur } \\
\text { s CEOs Age } \\
\text { Group }\end{array}$} & $20-29$ & 9 & 24 & 33 & 19.76 \\
\hline & $30-39$ & 20 & 21 & 41 & 24.55 \\
\hline & $40-49$ & 15 & 32 & 47 & 28.14 \\
\hline & 50 above & 21 & 25 & 46 & 27.54 \\
\hline & Chinese & 20 & 13 & 33 & 19.76 \\
\hline & Others & 2 & 0 & 2 & 1.20 \\
\hline \multirow{5}{*}{$\begin{array}{l}\text { SME } \\
\text { Entrepreneur } \\
\text { CEOs } \\
\text { Education } \\
\text { Level } \\
\end{array}$} & Postgraduate & 9 & 20 & 29 & 17.37 \\
\hline & Degree & 39 & 49 & 88 & 52.69 \\
\hline & Diploma & 5 & 16 & 21 & 12.57 \\
\hline & Secondary & 6 & 16 & 22 & 13.17 \\
\hline & Primary & 6 & 1 & 7 & 4.19 \\
\hline
\end{tabular}

Source: Own.

\section{Reliability and Validity}

Table 2 presents the construct reliability of this research and the values extend from 0.861 to 0.961 which is higher than the cut off value of 0.7 , which means that all the reflective constructs of this framework indicates internal consistency reliability. Therefore, it is safe to say that the measurements are reliable. From the SmartPLS analysis, it was found that loadings for several items (LOC10 and LOC7) were 0.04 and 0.596 and the AVE for LOC was 0.461 with CR of 0.807 . Hence, LOC10 and LOC7 were deleted and the new reading for the LOC AVE was 0.553. As per Hair 
et al. (2014) recommendation, loading between 0.4 and 0.7 ought to be given further attention. Items for Entrepreneurial Conceptual Competency also have loadings between 0.4 and 0.7. The items are ECC11 (0.657), ECC12 (0.559) and ECC13 (0.618). The ECC AVE before any deletion is 0.49 and CR was 0.869. Item ECC12 is first to be deleted because it has the lowest loading. After the ECC12 was deleted the ECC AVE was 0.525 and the CR was 0.868. Next, items ECC13 and ECC11 are deleted and the AVE and CR improve to 0.628 and 0.871. Items CI1 and CI5 loadings are 0.671 and 0.585 respectively with AVE and CR of 0.584 and 0.959. After deletion, the AVE for CI increases to 0.611 and the CR remains at 0.959 .

The items for 'Entrepreneurial Attitude Orientation Need for Achievement', 'Entrepreneurial Attitude Orientation Innovation', 'Market Orientation Customer Orientation', 'Market Orientation Competitor Orientation', 'Entrepreneurial Opportunity Competency', 'Entrepreneurial Relationship Competency', 'Entrepreneurial Strategic Competency', 'Entrepreneurial Technical Competency', and Innovative Performance are all retained after the loadings are checked for any inconsistency.

Table 2. Reliability of Reflective Constructs

\begin{tabular}{|c|c|c|c|c|c|}
\hline Constructs & Items & $\begin{array}{l}\text { Loading } \\
\mathrm{s}\end{array}$ & AVE & CR & $\begin{array}{l}\text { Item(s) deleted due } \\
\text { to low loadings }\end{array}$ \\
\hline \multirow{4}{*}{ EAO NFA } & NFA1 & 0.875 & 0.776 & 0.933 & \\
\hline & NFA2 & 0.887 & & & \\
\hline & NFA3 & 0.892 & & & \\
\hline & NFA4 & 0.870 & & & \\
\hline \multirow[t]{4}{*}{ EAOLOC } & LOC5 & 0.834 & 0.611 & 0.861 & LOC7 \\
\hline & LOC6 & 0.786 & & & LOC10 \\
\hline & LOC8 & 0.854 & & & \\
\hline & LOC9 & 0.632 & & & \\
\hline \multirow[t]{5}{*}{ EAOINNV } & INNV11 & 0.797 & 0.618 & 0.890 & \\
\hline & INNV12 & 0.724 & & & \\
\hline & INNV13 & 0.855 & & & \\
\hline & INNV14 & 0.844 & & & \\
\hline & INNV15 & 0.701 & & & \\
\hline \multirow[t]{5}{*}{ CustOrient } & CUSOrient1 & 0.759 & 0.717 & 0.927 & \\
\hline & CUSOrient2 & 0.859 & & & \\
\hline & CUSOrient3 & 0.889 & & & \\
\hline & CUSOrient4 & 0.876 & & & \\
\hline & CUSOrient5 & 0.845 & & & \\
\hline \multirow[t]{3}{*}{ CompOrient } & $\begin{array}{l}\text { COMOreint } \\
6\end{array}$ & 0.890 & 0.789 & 0.918 & \\
\hline & $\begin{array}{l}\text { COMOrient } \\
7\end{array}$ & 0.885 & & & \\
\hline & $\begin{array}{l}\text { COMOrient } \\
8\end{array}$ & 0.890 & & & \\
\hline \multirow[t]{2}{*}{ Strategic Comp } & ECS1 & 0.755 & 0.652 & 0.944 & \\
\hline & ECS2 & 0.743 & & & \\
\hline
\end{tabular}




\begin{tabular}{|c|c|c|c|c|c|}
\hline & ECS3 & 0.849 & & & \\
\hline & ECS4 & 0.782 & & & \\
\hline & ECS5 & 0.866 & & & \\
\hline & ECS6 & 0.787 & & & \\
\hline & ECS7 & 0.852 & & & \\
\hline & ECS8 & 0.854 & & & \\
\hline & ECS9 & 0.769 & & & \\
\hline \multirow{4}{*}{$\begin{array}{l}\text { Conceptual } \\
\text { Comp }\end{array}$} & ECC10 & 0.751 & 0.628 & 0.871 & ECC11 \\
\hline & ECC14 & 0.808 & & & ECC12 \\
\hline & ECC15 & 0.802 & & & ECC13 \\
\hline & ECC16 & 0.806 & & & \\
\hline \multirow{4}{*}{$\begin{array}{l}\text { Opportunity } \\
\text { Comp }\end{array}$} & ECO17 & 0.845 & 0.681 & 0.895 & \\
\hline & ECO18 & 0.804 & & & \\
\hline & ECO19 & 0.847 & & & \\
\hline & ECO20 & 0.805 & & & \\
\hline \multirow{6}{*}{$\begin{array}{l}\text { Relationship } \\
\text { Comp }\end{array}$} & ECR21 & 0.757 & 0.608 & 0.903 & \\
\hline & ECR22 & 0.783 & & & \\
\hline & ECR23 & 0.818 & & & \\
\hline & ECR24 & 0.758 & & & \\
\hline & ECR25 & 0.776 & & & \\
\hline & ECR26 & 0.787 & & & \\
\hline \multirow{4}{*}{$\begin{array}{l}\text { Technical } \\
\text { Comp }\end{array}$} & ЕCT27 & 0.795 & 0.689 & 0.898 & \\
\hline & ЕСТ28 & 0.812 & & & \\
\hline & ЕСТ29 & 0.828 & & & \\
\hline & ECT30 & 0.882 & & & \\
\hline \multirow[t]{14}{*}{ CI } & CI2 & 0.753 & 0.608 & 0.961 & $\mathrm{C} 1$ \\
\hline & $\mathrm{CI} 3$ & 0.734 & & & $\mathrm{C} 5$ \\
\hline & CI4 & 0.752 & & & \\
\hline & CI6 & 0.771 & & & \\
\hline & CI7 & 0.829 & & & \\
\hline & CI8 & 0.829 & & & \\
\hline & CI9 & 0.755 & & & \\
\hline & CI10 & 0.763 & & & \\
\hline & CI11 & 0.763 & & & \\
\hline & CI12 & 0.837 & & & \\
\hline & CI13 & 0.837 & & & \\
\hline & CI14 & 0.773 & & & \\
\hline & CI15 & 0.839 & & & \\
\hline & CI16 & 0.683 & & & \\
\hline \multirow[t]{6}{*}{ IP } & IP1 & 0.800 & 0.587 & 0.895 & \\
\hline & IP2 & 0.799 & & & \\
\hline & IP3 & 0.791 & & & \\
\hline & IP4 & 0.652 & & & \\
\hline & IP5 & 0.767 & & & \\
\hline & IP6 & 0.779 & & & \\
\hline
\end{tabular}


Note: Loadings $>0.7, A V E>0.5, C R>0.7$

Source: Own.

To test the discriminant validity, an analysis of the loadings and cross loadings outputs are conducted to detect discriminant validity problem. Table 3 also shows that the square root of the AVEs for each construct is higher than the correlation for each construct which also indicates adequate discriminant validity for the constructs recommended in this study.

Table 3. Discriminant Validity of Construct

\begin{tabular}{|c|c|c|c|c|c|c|c|c|c|c|c|c|}
\hline & CI & $\mathrm{CO}$ & CUS & $\begin{array}{l}\text { EAO } \\
\text { INN }\end{array}$ & $\begin{array}{l}\text { EAO } \\
\text { LOC }\end{array}$ & $\begin{array}{l}\text { EAO } \\
\text { NFA }\end{array}$ & ECC & ECO & ECR & ECS & EC & IP \\
\hline CI & 0.780 & & & & & & & & & & & \\
\hline $\mathrm{CO}$ & 0.540 & 0.888 & & & & & & & & & & \\
\hline CUS & 0.405 & 0.673 & 0.847 & & & & & & & & & \\
\hline $\begin{array}{l}\text { EAO } \\
\text { INN }\end{array}$ & 0.496 & 0.504 & 0.510 & 0.786 & & & & & & & & \\
\hline $\begin{array}{l}\text { EAO } \\
\text { LOC }\end{array}$ & 0.421 & 0.517 & 0.615 & 0.718 & 0.781 & & & & & & & \\
\hline $\begin{array}{l}\text { EAO } \\
\text { NFA }\end{array}$ & 0.348 & 0.368 & 0.413 & 0.428 & 0.647 & 0.881 & & & & & & \\
\hline ECC & 0.630 & 0.622 & 0.565 & 0.567 & 0.514 & 0.404 & 0.792 & & & & & \\
\hline ECO & 0.576 & 0.635 & 0.567 & 0.523 & 0.480 & 0.391 & 0.785 & 0.825 & & & & \\
\hline ECR & 0.571 & 0.590 & 0.510 & 0.601 & 0.437 & 0.302 & 0.713 & 0.658 & 0.780 & & & \\
\hline ECS & 0.585 & 0.640 & 0.633 & 0.459 & 0.542 & 0.411 & 0.656 & 0.667 & 0.668 & 0.808 & & \\
\hline ECT & 0.603 & 0.451 & 0.416 & 0.463 & 0.455 & 0.174 & 0.670 & 0.570 & 0.658 & 0.663 & 0.830 & \\
\hline IP & 0.662 & 0.464 & 0.452 & 0.462 & 0.455 & 0.300 & 0.609 & 0.577 & 0.513 & 0.576 & 0.507 & 0.766 \\
\hline
\end{tabular}

Note: Values in the diagonal (bolded) represent the square root of the AVE while the off diagonals are correlations

Source: Own.

\section{Structural Model Direct Relationship}

In this research, all the endogenous variables seem to have R2 values between 0.318 and 0.509. As suggested by Cohen (1988), R2 values between 0.02 and 0.12 are small, 0.13 to 0.25 is moderate, and above 0.26 is considered substantial. Since the $\mathrm{R} 2$ for the endogenous variables are above 0.26 , an assumption is made that the model used in this study fits the data well. The structural model is tested for the first thirty-one hypotheses. From Table 4, out of the thirty-one hypotheses, only twentyone hypotheses fulfill the statistical conditions. These are $\mathrm{H} 1, \mathrm{H} 3, \mathrm{H} 9, \mathrm{H} 10, \mathrm{H} 11$, H12, H13, H15, H16, H17, H18, H19, H21 H22, H23, H24, H25, H28, H29, H30, and H31. The relationship between Competitive Intelligence and Innovative Performance is particularly noticeable as it has a positive effect with $\beta$ value at $0.662, \rho<0.01$ significance level, and t-value equals 15.968 .

Table 4. Hypothesis Testing

\begin{tabular}{|c|c|c|c|c|c|}
\hline Hypothesis & Relationship & $\begin{array}{l}\text { Standard } \\
\beta\end{array}$ & $\begin{array}{l}\text { Stan } \\
\text { Error } \\
\end{array}$ & t-Value & Decision \\
\hline $\begin{array}{l}\text { Hypothesis } \\
1\end{array}$ & $\begin{array}{l}\text { EAO NFA -> } \\
\text { ECOpportunity }\end{array}$ & 0.127 & 0.081 & $1.565^{*}$ & Supported \\
\hline
\end{tabular}




\begin{tabular}{|c|c|c|c|c|c|}
\hline $\begin{array}{l}\text { Hypothesis } \\
2\end{array}$ & $\begin{array}{l}\text { EAO NFA -> } \\
\text { ECRelationship }\end{array}$ & 0.041 & 0.073 & 0.561 & $\begin{array}{l}\text { Not } \\
\text { Supported }\end{array}$ \\
\hline $\begin{array}{l}\text { Hypothesis } \\
3\end{array}$ & $\begin{array}{l}\text { EAO NFA -> } \\
\text { ECConceptual }\end{array}$ & 0.119 & 0.079 & $1.493 *$ & Supported \\
\hline $\begin{array}{l}\text { Hypothesis } \\
4\end{array}$ & $\begin{array}{l}\text { EAO NFA -> } \\
\text { ECStrategic }\end{array}$ & 0.078 & 0.071 & 1.097 & $\begin{array}{l}\text { Not } \\
\text { Supported }\end{array}$ \\
\hline $\begin{array}{l}\text { Hypothesis } \\
5\end{array}$ & $\begin{array}{l}\text { EAO NFA -> } \\
\text { ECTechnical }\end{array}$ & -0.210 & 0.086 & 2.460 & $\begin{array}{l}\text { Not } \\
\text { Supported }\end{array}$ \\
\hline $\begin{array}{l}\text { Hypothesis } \\
6\end{array}$ & $\begin{array}{l}\text { EAO LOC -> } \\
\text { ECOpportunity }\end{array}$ & -0.093 & 0.115 & 0.808 & $\begin{array}{l}\text { Not } \\
\text { Supported }\end{array}$ \\
\hline $\begin{array}{l}\text { Hypothesis } \\
7\end{array}$ & $\begin{array}{l}\text { EAO LOC } \rightarrow \\
\text { ECRelationship }\end{array}$ & -0.199 & 0.108 & 1.856 & $\begin{array}{l}\text { Not } \\
\text { Supported }\end{array}$ \\
\hline $\begin{array}{l}\text { Hypothesis } \\
8\end{array}$ & $\begin{array}{l}\text { EAO LOC -> } \\
\text { ECConceptual }\end{array}$ & -0.061 & 0.102 & 0.599 & $\begin{array}{l}\text { Not } \\
\text { Supported }\end{array}$ \\
\hline $\begin{array}{l}\text { Hypothesis } \\
9\end{array}$ & $\begin{array}{l}\text { EAO LOC -> } \\
\text { ECStrategic }\end{array}$ & 0.128 & 0.097 & $1.322 *$ & Supported \\
\hline $\begin{array}{l}\text { Hypothesis } \\
10\end{array}$ & $\begin{array}{l}\text { EAO LOC -> } \\
\text { ECTechnical }\end{array}$ & 0.289 & 0.129 & $2.248 * *$ & Supported \\
\hline $\begin{array}{l}\text { Hypothesis } \\
11\end{array}$ & $\begin{array}{l}\text { EAO INNV -> } \\
\text { ECOpportunity }\end{array}$ & 0.245 & 0.088 & $2.768 * * *$ & Supported \\
\hline $\begin{array}{l}\text { Hypothesis } \\
12\end{array}$ & $\begin{array}{l}\text { EAO INNV -> } \\
\text { ECRelationship }\end{array}$ & 0.484 & 0.087 & $5.565 * * *$ & Supported \\
\hline $\begin{array}{l}\text { Hypothesis } \\
13\end{array}$ & $\begin{array}{l}\text { EAO INNV -> } \\
\text { ECConceptual }\end{array}$ & 0.301 & 0.080 & $3.740 * * *$ & Supported \\
\hline $\begin{array}{l}\text { Hypothesis } \\
14\end{array}$ & $\begin{array}{l}\text { EAO INNV -> } \\
\text { ECStrategic }\end{array}$ & 0.015 & 0.080 & 0.195 & $\begin{array}{l}\text { Not } \\
\text { Supported }\end{array}$ \\
\hline $\begin{array}{l}\text { Hypothesis } \\
15\end{array}$ & $\begin{array}{l}\text { EAO INNV -> } \\
\text { ECTechnical }\end{array}$ & 0.191 & 0.107 & $1.789 * *$ & Supported \\
\hline $\begin{array}{l}\text { Hypothesis } \\
16\end{array}$ & $\begin{array}{l}\text { CUSOrient -> } \\
\text { ECOpportunity }\end{array}$ & 0.185 & 0.085 & $2.178 * *$ & Supported \\
\hline $\begin{array}{l}\text { Hypothesis } \\
17\end{array}$ & $\begin{array}{l}\text { CUSOrient -> } \\
\text { ECRelationship }\end{array}$ & 0.141 & 0.091 & $1.548^{*}$ & Supported \\
\hline $\begin{array}{l}\text { Hypothesis } \\
18\end{array}$ & $\begin{array}{l}\text { CUSOrient -> } \\
\text { ECConceptual }\end{array}$ & 0.167 & 0.084 & $2.002 * *$ & Supported \\
\hline $\begin{array}{l}\text { Hypothesis } \\
19\end{array}$ & $\begin{array}{l}\text { CUSOrient -> } \\
\text { ECStrategic }\end{array}$ & 0.278 & 0.094 & $2.967 * * *$ & Supported \\
\hline $\begin{array}{l}\text { Hypothesis } \\
20\end{array}$ & $\begin{array}{l}\text { CUSOrient -> } \\
\text { ECTechnical }\end{array}$ & 0.068 & 0.154 & 0.442 & $\begin{array}{l}\text { Not } \\
\text { Supported }\end{array}$ \\
\hline $\begin{array}{l}\text { Hypothesis } \\
21\end{array}$ & $\begin{array}{l}\text { COMPOrient -> } \\
\text { ECOpportunity }\end{array}$ & 0.389 & 0.084 & $4.644 * * *$ & Supported \\
\hline $\begin{array}{l}\text { Hypothesis } \\
22\end{array}$ & $\begin{array}{l}\text { COMPOrient -> } \\
\text { ECRelationship }\end{array}$ & 0.339 & 0.074 & $4.591 * * *$ & Supported \\
\hline $\begin{array}{l}\text { Hypothesis } \\
23\end{array}$ & $\begin{array}{l}\text { COMPOrient -> } \\
\text { ECConceptual }\end{array}$ & 0.346 & 0.087 & $3.973 * * *$ & Supported \\
\hline $\begin{array}{l}\text { Hypothesis } \\
24\end{array}$ & $\begin{array}{l}\text { COMPOrient -> } \\
\text { ECStrategic }\end{array}$ & 0.351 & 0.086 & $4.085 * * *$ & Supported \\
\hline $\begin{array}{l}\text { Hypothesis } \\
25\end{array}$ & $\begin{array}{l}\text { COMPOrient -> } \\
\text { ECTechnical }\end{array}$ & 0.237 & 0.132 & $1.803 * *$ & Supported \\
\hline Hypothesis & ECOpportunity & 0.104 & 0.110 & 0.946 & Not \\
\hline
\end{tabular}




\begin{tabular}{|c|c|c|c|c|c|}
\hline 26 & $->\mathrm{CI}$ & & & & Supported \\
\hline $\begin{array}{l}\text { Hypothesis } \\
27\end{array}$ & $\begin{array}{l}\text { ECRelationship } \\
->\text { CI }\end{array}$ & 0.078 & 0.092 & 0.840 & $\begin{array}{l}\text { Not } \\
\text { Supported }\end{array}$ \\
\hline $\begin{array}{l}\text { Hypothesis } \\
28\end{array}$ & $\begin{array}{l}\text { ECConceptual - } \\
>\text { CI }\end{array}$ & 0.235 & 0.121 & $1.940 * *$ & Supported \\
\hline $\begin{array}{l}\text { Hypothesis } \\
29\end{array}$ & $\begin{array}{l}\text { ECStrategic } \rightarrow \\
\text { CI }\end{array}$ & 0.156 & 0.092 & $1.698 * *$ & Supported \\
\hline $\begin{array}{l}\text { Hypothesis } \\
30\end{array}$ & $\begin{array}{l}\text { ECTechnical -> } \\
\text { CI }\end{array}$ & 0.232 & 0.081 & $2.870 * * *$ & Supported \\
\hline $\begin{array}{l}\text { Hypothesis } \\
31\end{array}$ & CI $\rightarrow$ IP & 0.662 & 0.041 & $15.968 * * *$ & Supported \\
\hline
\end{tabular}

Note: $* * * p<0.01(2.33), * * p<0.05(1.645), *_{p}<0.10(1.28)$

Source: Own.

\section{Mediating Effect}

Hypotheses 32 to 36 propose that competitive intelligence mediates the relationship between opportunity competency, relationship competency, conceptual competency, strategic competency and technical competency with innovative performance. From Table 6, it is discovered that $\mathrm{H} 34, \mathrm{H} 35$ and $\mathrm{H} 36$ fulfil the conditions required for a mediating effect with a $95 \%$ and $99 \%$ significance levels. Table 5 reveals that conceptual, strategic and technical entrepreneurial competencies are positively mediated by competitive intelligence. Thus, the indirect effect is statistically significant.

Table 5. Summary of Mediating Results

\begin{tabular}{|c|c|c|c|c|c|c|c|}
\hline \multirow{2}{*}{$\begin{array}{l} \\
\text { Hypothesi } \\
\text { s }\end{array}$} & \multirow[b]{2}{*}{$\begin{array}{l}\text { Path } \\
\text { a }\end{array}$} & \multirow[b]{2}{*}{$\begin{array}{l}\text { Path } \\
\text { b }\end{array}$} & \multirow[b]{2}{*}{$\begin{array}{l}\text { Indirec } \\
\text { t Effect }\end{array}$} & \multirow[b]{2}{*}{ SE } & \multirow[b]{2}{*}{ t-value } & \multicolumn{2}{|c|}{$\begin{array}{l}\text { Bootstrapped } \\
\text { Conf. Interva }\end{array}$} \\
\hline & & & & & & $\begin{array}{l}95 \% \\
\text { LL }\end{array}$ & $\begin{array}{l}95 \% \\
\text { UL }\end{array}$ \\
\hline H32 & 0.104 & 0.66 & 0.069 & 0.04926 & 1.402 & -0.027 & 0.166 \\
\hline H33 & 0.078 & 0.66 & 0.051 & 0.05034 & 0.049 & -0.047 & 0.150 \\
\hline H34 & 0.235 & 0.66 & 0.155 & 0.07686 & $2.021 * *$ & 0.005 & 0.306 \\
\hline H35 & 0.156 & 0.66 & 0.104 & 0.00931 & $11.11 * * *$ & 0.085 & 0.122 \\
\hline H36 & 0.232 & 0.66 & 0.154 & 0.06765 & $2.270 * * *$ & 0.021 & 0.286 \\
\hline
\end{tabular}

Note: $* * * \mathrm{p}<0.01(2.33),{ }^{* *} \mathrm{p}<0.05(1.645),{ }^{*} \mathrm{p}<0.10(1.28)$

Source: Own.

Predictive Relevance $\left(Q^{2}\right)$

In SmartPLS, the omission distance is between 5 and 10 and is used to value the predictive relevance. The omission distance in this study is 6 . The study found a cross-validated redundancy Q2 of 0.322 and a cross-validated commonality of 0.676 for Entrepreneurial Opportunity Competency 0.293 and 0.610 for Entrepreneurial Relationship Competency, 0.304 and 0.622 for Entrepreneurial Conceptual Competency, 0.329 and 0.647 for Entrepreneurial Strategic Competency, 0.219 and 0.699 for Entrepreneurial Technical Competency and finally a cross-validated redundancy Q2 of 0.282 and a cross-validated commonality of 0.553 for 
Competitive Intelligence. The Q2 values are greater than 0 , which shows that the model has considerable predictive relevance. Table 6 represents the predictive relevance values.

Table 6. Blindfolding Result: CV-Redundancy and CV-Communality

\begin{tabular}{lll}
\hline Endogenous Variables & $\mathbf{C V}(\mathbf{R e d}) \mathbf{Q}^{\mathbf{2}}$ & $\mathbf{C V}(\mathbf{C o m}) \mathbf{H}^{\mathbf{2}}$ \\
\hline Entrepreneurial Opportunity Competency & 0.322 & 0.676 \\
Entrepreneurial Relationship Competency & 0.293 & 0.610 \\
Entrepreneurial Conceptual Competency & 0.304 & 0.622 \\
Entrepreneurial Strategic Competency & 0.329 & 0.647 \\
Entrepreneurial Technical Competency & 0.219 & 0.699 \\
Competitive Intelligence & 0.282 & 0.553 \\
Innovative Performance & 0.247 & 0.570 \\
\hline
\end{tabular}

Source: Own.

Global Criterion of Goodness of Fit measure

In Table 7 , the GoF value is 0.548 which bypasses the value of 0.36 estimation of large effect size $\mathrm{R}^{2}$. Therefore, the $\mathrm{GoF}$ of 0.548 indicates that the statistical approach has a finer prediction power in contrast to the baseline values and offers sufficient support to validate the PLS model globally (Wetzels et al., 2009).

Table 7. Goodness of Fit (GoF)

\begin{tabular}{lll}
\hline Construct & AVE & $\mathbf{R}^{\mathbf{2}}$ \\
\hline EAO Need For Achievement & 0.776 & \\
EAO Locus Of Control & 0.611 & \\
& & \\
EAO Innovation & 0.618 & \\
Customer Orientation & 0.717 & \\
Competitor Orientation & 0.789 & 0.485 \\
Entrepreneurial Opportunity Competency & 0.681 & 0.488 \\
Entrepreneurial Relationship Competency & 0.608 & 0.497 \\
Entrepreneurial Conceptual Competency & 0.628 & 0.509 \\
Entrepreneurial Strategic Competency & 0.652 & 0.318 \\
Entrepreneurial Technical Competency & 0.689 & 0.484 \\
Competitive Intelligence & 0.608 & 0.438 \\
Innovative Performance & 0.587 & $\mathbf{0 . 4 6 0}$ \\
\hline AVERAGE & $\mathbf{0 . 6 5 4}$ & \\
\hline SOurce: Own & & \\
\hline
\end{tabular}

Source: Own.

\section{Discussion and Conclusions}

The results show that two EAO (LoC and innovativeness) constructs positively influence specific entrepreneurial competencies. The results indicate that market orientation has a positive impact on entrepreneurial competencies. The results also reveal that three out of the five constructs, namely conceptual competency, strategic competency, and technical competency, positively influence competitive 
intelligence. Competitive intelligence result also positively influences innovative performance. It is found that competitive intelligence functions as an intermediary for only conceptual competency, strategic competency, and technical competency.

To achieve similar economic status as its neighbors like Taiwan and the Republic of Korea, Malaysia must create effective game plans. This research offers several important theoretical inferences for academics. This research provides realistic evidence on competitive intelligence's contribution as an intermediary between entrepreneurial attitude orientation, entrepreneurial competencies, market orientation, and innovative performance. This study, which sets out to link five entrepreneurial competencies to innovative performance, has provided empirical evidence that competitive intelligence does strengthen the relationship between entrepreneurial competencies, especially the specific competencies and innovative performance in Malaysian SMEs. While this finding suggests its relevance to SMEs' experience in the developing world, its implication may be relevant to the SMEs in general regardless of country status. This study affirms the RBV, which acknowledges that entrepreneurs may achieve competitive/innovative advantage by harnessing particularly internal factors from the organization's resources. Two constructs of entrepreneurial attitude orientation and market orientation are both confirmed by this study as antecedents of entrepreneurial competencies. They are cognitive and aptitude behavioural mechanisms behavioral essential for the achievement of innovative performance. While the study focuses on entrepreneurs, its findings are relevant to all private and public industries' levels. Through the inculcation of the pertinent elements of entrepreneurial attitude in the rank and file, a culture of innovativeness and enhanced thinking skill can be engendered on a wider scale.

To inculcate an innovative mindset requires no less than a solid commitment of management to its cause; it is defining innovation behavior as the foundation upon which the organization rest. It is recommended that the organizations review their human capital development plans periodically to check on innovative performance progress. The human resource practitioners can tailor use the EAO constructs of need for achievement and locus of control on specific individuals rather than generalizing their use to all. The organizations should be convinced that entrepreneurial attitude orientation could positively influence strategic thinking among the rank and file on the outset. This fits in well with the new economic paradigm characterized by self-analysis, self-reliance, and self-renewal (Sewdass \& Toit, 2014). Government agencies must acknowledge that the managerial, entrepreneurial, and technical competencies are required to operate an SME is different from an MNC. Thus the programs designed for SMEs must be tailor-made to fit the SME requirement. The key for Malaysian SMEs to achieve entrepreneurial growth lies in the innovation adoption, rather than through managerial influence. 


\section{References:}

Baregheh, Anahita., Rowley, Jennifer., Sambrook, Sally., Davies, Daffyd. 2012. Innovation in food sector SMEs. Journal of Small Business and Enterprise Development, 19(2), 300-321. doi: 10.1108/14626001211223919

Bird, B. 1995. Toward a theory of entrepreneurial competency. In J.A. Katz \& R.H. Brockhaus (Eds.), Advances in entrepreneurship, firm emergence, and growth (Vol. 2, 51-72. Greenwich, CT: JAI press.

Calof, J. 2012. Event intelligence through the eye of an old crow. Competitive Intelligence Magazine, 15(3), 56-60.

Carrier, C. 2007. Strategies for teaching entrepreneurship: What else beyond lectures, case studies and business plans. In A. Fayolle (Ed.), Handbook of Research in Entrepreneurship Education. A General Perspective (Vol.1, 143-159). Northampton, MA: Edward Elgar Publishing Limited.

Charity, A.E., Joseph, I.U. 2013. Manage competitive intelligence for strategic advantage. European Journal of Business and Management, 5(3), 1-9.

Choe, Kum-Lung, Loo, Siat-Ching, Lau, Teck-Chai. 2013. Exploratory Study on the Relationship between Entrepreneurial Attitude and Firm's Performance. Asian Social Science, 9(4), 144.

Daft, R. 1983. Organization theory and design. New York, NY: West.

Damanpour, Fariborz. 1996. Organizational complexity and innovation: Developing and testing multiple contingency models. Management Science, 42(5), 693-716.

Faul, F., Erdfelder, E., Buchner, A., Lang, A.G. 2009. Statistical power analyses using G*Power 3.1: Tests for correlation and regression analysis. Behavior Research Methods, 58(1) 164-199

Freel, M., de Jong, J.P.J. 2009. Market novelty, competence-seeking and innovation networking Technovation, 29(12), 873-884.

Hair, J.F., Black, W.C., Babin, B.J., Anderson, R.E. 2010. Multivariate data analysis. Upper saddle River, NJ: Pearson Education, Inc.

Hair, J.F., Hult, G. Tomas M., Ringle, C.M., Sarstedt, M. 2014. A primer on partil least squares structural equation modeling (PLS-SEM). Los Angeles, USA: SAGE Publications, Inc.

Hayes, A.F. 2009. Beyond Baron and Kenny: Statistical mediation analysis in the new millennium. Communication Monographs, 76(4), 408-420.

Heslina, Payangan, O.R., Taba, M.I., Pabo, M.I. 2016. Factors affecting the business performance of the micro, small and medium enterprises in creative economic sector in Makassar, Indonesia. Scientific Research Journal, 5(1), 41-49.

Hunt, S., Lambe, J. 2000. Marketing's contribution to business strategy: Market orientation, relationship marketing and resource-advantage theory. International Journal of Management Reviews, 2(1), 17-43.

Hussein, Rezaie Dollatabady, Farzaneh, Ghandehari, Amiri, Farham. 2011. Analyzing the impact of competitive intelligence on innovation at scientific research centers. In Isfahan science and technology town. Interdisciplinary Journal of Contemporary Research in Business, 3(5), 940-948.

Kim, Youngbae, Ha, Seongwook. 2010. Innovation activities and innovation performances of SMEs: The Korean electronic parts industry 1990-1995. Asian Journal of Technology Innovation, 18(1), 125-160. 
Kumar, M., Sanchez Rodrigues, V. 2020. Synergetic effect of lean and green on innovation: A resource-based perspective. International Journal of Production Economics 219, 469-479

Larivet, S. 2009. Economic intelligence in small and medium business in France: A survey Paper presented at the 3rd European Competitve Intelligence Symposium. Mälardalen University Stockholm, Sweden.

Man, Thomas W.Y., Lau, T., Chan, K.F. 2002. The competitiveness of small and medium enterprises: A conceptualization with focus on entrepreneurial competencies. Journal of Business Venturing, 17(2), 23-142.

Maritz, Rachel, du Toit, Adeline. 2018. The practice turn within strategy: Competitive intelligence as integrating practice. South African Journal of Economic and Management Sciences , 21(1), 1-14.

Nag, R., Neville, F., Dimotakis, N. 2020. CEO scanning behaviours, self-efficacy, and SME innovation and performance: An examination within a declining industry. Journal of Small Business Management, 58(1), 164-199.

Narver, J.C., Slater, S.F. 1990. The effect of a market orientation on business profitability. Journal of Marketing, 54(4), 20-35.

Pramod, I., Paswan, A. 2019. Market Orientation, positioning strategy and brand performance. Industrial Marketing Management, 81, 16-29

Pihie, Zaidatol Akmaliah Lope, Bagheri, Afsaneh. 2010. Malay students' entrepreneurial attitude and entrepreneurial efficacy in vocational and technical secondary schools of Malaysia. Journal of Vocational Education \& Training, 62(3), 351-366.

Poon, W.C., Mohamad, O., Wan Yusoff, Wan Fadzilah. 2018. Examining the antecedents of ambidextrous behaviours in promoting creativity among SMEs in Malaysia. Global Business Review, 21(3), 645-662.

Qiu, Tianjiao. 2008. Scanning for competitive intelligence: a managerial perspective. European Journal of Marketing, 42(7), 814-835.

Ratnawati, Soetjipto, B.E., Murwani, F.D., Hari Wahyono, H. 2018. The role of SMEs' innovation and learning orientation in mediating the effect of CSR programme on SMEs' performance and competitive advantage. Global Business Review, 19(3), 21-38.

Rogers, E. 2008. Diffusion of innovations: New York: Free Press.

Sánchez-Báez, E.A, Fernández-Serrano,J., Romero, I. 2018. Personal values and entrepreneurial attitude as intellectual capital: Impact on innovation in small enterprises. Amfiteatru Economic, 20(49), 771-787.

Sewdass, N., Toit, A.Du. 2014. Current state of competitive intelligence in South Africa. International Journal of Information Management, 34(2), 185-190.

Shariff, Mohd Noor Mohd., Saud, Mohammad Basir. 2009. An attitude approach to the prediction of entrepreneurship on students at institution of higher learning in Malaysia. International Journal of Business and Management, 4(4), P129.

Smith, J.R., Wright, S., Pickton, D. 2010. Competitive intelligence programmes for SMEs in France: Evidence of changing attitudes. Journal of Strategic Marketing, 18(7), 523-536.

Stokes, D., Blackburn, R. 2002. Learning the hard way: The lessons of owner managermanagers who have closed their businesses. Journal of Small Business and Enterprise Development, 9(1), 17-27. 
Taipale-Erävala, K., Henttonen, K., Lampela, H. 2019. Entrepreneurial competencies in successfully innovative SMEs. International Journal of Entrepreneurship and Small Business, Published online Oct 30.

Tarraf, P., Molz, R. 2006. Competitive intelligence at small enterprises. SAM Advanced Management Journal (07497075), 71(4), 24-34.

Tarek, B.H., Zouhayer, M., Adel, G. 2019. Entrepreneurial competitive intelligence between Uppsala Model and born global theories in the case of North African SMEs. Journal of the Knolwedge Economy, 10(20), 734-755.

Thalassinos, I.E., Thalassinos, E.Y. 2018. Financial Crises and e-Commerce: How Are They Related? Available at SSRN: https://ssrn.com/abstract=3330169.

Tripsas, M., Gavetti, G. 2000. Capabilities, cognition, and inertia: evidence from digital imaging. Strategic Management Journal, 21(10), 1147-1161.

Tywoniak, S. 2007. Making sense of the resource-based view? Paper presented at the Academy of Management Conference - Doing well by doing good, Philadelphia.

Vamvaka, V., Stoforos,C., Palaskas, T. et al. 2020. Attitude toward entreprenership, perceived behavioral control, and entrepreneurial intention: dimensionaity, structural relationships, and gender differences, Journal of Innovation and Entrepreneurship, 9(5), 1-26

Vijaya,C., Manjula, D., Mitrabindha, D. 2015. Entrepreneurship competencies and competitive advantage of small and medium entrperprises of Odisha - A statistical analysis. Internatonal Journal of Management, 6(1), 740-757.

Wetzels, M, Odekerken-Schroder, G., Van Oppen, C. 2009. Using PLS path modeling for assessing hierarchical construct models: guidelines and empirical illustration. Management Information Systems Quarterly, 33(1), 177-195.

Zha, X., Chen, M. 2009. Competitive intelligence monitoring in the risk prevention of SMEs. Journal of Service Science and Management, 3, 230-235. doi:10.4236/jssm.2009.23028

Zheng, S., Zhang, W., Du, J. 2011. Knowledge-based dynamic capabilities and innovation in networked environments. Journal of Knowledge Management, 15(6), 1035-1051.

Zhou, S., Zhou, A., Feng, J., Jiang, S. 2019. Dynamic capabilities and organisational performance: The mediating role of innovation. Journal of Management \& Organisation, 25(5), 731-747. 